\title{
Влияние полиморфизма генов биотрансформации ксенобиотиков на течение муковисцидоза и риск развития нежелательных побочных реакций на антибактериальную терапию
}

\author{
Новоселова О. Г. ${ }^{1}$ Кондратьева Е. И. ${ }^{2}$, Петрова Н. В. ${ }^{2}$, Кондакова Ю. А. ${ }^{3}$, Зинченко Р. А. ${ }^{2,4}$ \\ 1 - Государственное бюджетное учреждение здравоохранения города Москвы «Детская городская клиническая \\ больница имени Н.Ф. Филатова Департамента здравоохранения города Москвы» Москва, Россия \\ 2 - Федеральное государственное бюджетное научное учреждение «Медико-генетический научный центр \\ имени академика Н.П. Бочкова», Москва, Россия \\ 3 - Федеральное государственное автономное образовательное учреждение высшего образования \\ «Российский университет дружбы народов», Москва, Россия \\ 4 - Федеральное государственное автономное образовательное учреждение высшего образования \\ «Российский национальный исследовательский медицинский университет имени Н.И. Пирогова» \\ Министерства здравоохранения Российской Федерации, Москва, Россия
}

Ключевые слова: полиморфизм генов; ксенобиотики; муковисцидоз; антибактериальная терапия; побочные реакции

Для цитирования:

Новоселова О. Г., Кондратьева Е. И., Петрова Н. В., Кондакова Ю. А., Зинченко Р. А. Влияние полиморфизма генов биотрансформации ксенобиотиков на течение муковисцидоза и риск развития нежелательных побочных реакций на антибактериальную терапию. Фармакогенетика и фармакогеномика. 2021;(2):14-15. (In Russ). https://doi.org/10.37489/2588-0527-2021-2-14-15

\section{Введение}

Муковисцидоз (МВ) - наследственное моногенное заболевание с аутосомно-рецессивным типом передачи, обусловленное мутациями гена CFTR. При МВ эффективность антибактериальной терапии (АБТ) респираторной инфекции определяет прогноз течения заболевания, продолжительность и качество жизни пациентов [1-3]. Лекарственные средства (ЛС) в организме человека под действием ферментов биотрансформации ксенобиотиков (ФБК) I и II фазы превращаются в активные или неактивные соединения, обеспечивающие терапевтический эффект. Выяснение причин неэффективности антибактериальной терапии и нежелательных побочных реакций (НПР) при МВ является перспективным и может решить обозначенные проблемы для популяции в целом [4].

\section{Цель}

Изучение влияния полиморфных вариантов генов I и II фазы биотрансформации ксенобиотиков на течение заболевания, эффективность антибактериальной терапии, развитие и частоту нежелательных побочных реакций у пациентов с муковисцидозом для обоснования новых подходов к персонализированной антибактериальной терапии.

\section{Материалы и методы}

Материалом для исследования явились образцы ДНК и клинико-анамнестические данные о 333 пациентах с МВ (223 - из РФ, 110 - из РБ). Соотношение по полу 170 мужчин : 163 женщин $(0,51$ : 0,49). Средний возраст составил 9,77 \pm 7,38 лет (от 0,36 до 40,35 лет). Для фармакокинетического исследования использованы образцы крови 33 пациентов с МВ из общей группы больных. Взаимосвязь фармакогенетических и фармакокинетических параметров была изучена на примере ципрофлоксацина (основного препарата для лечения синегнойной инфекции) $[3,5]$.

\section{Результаты}

Выявлена ассоциация генотипов GG гена CYP2D6 (CYP2D6*4) $(\mathrm{OR}(\mathrm{GG})=1,703 ; 95$ \% CI 1,036-2,800)), CC гена GCLC (c.-129C>T) с хронической колонизацией слизистой респираторного тракта Pseudomonas 
aeruginosa и другой грамотрицательной микрофлорой. Снижения функции лёгких - с генотипами АA гена CYP2C9 (CYP2C9*3) (OR(AA) = 2,571; 95 \% CI 1,161-5,696)), AA и AG гена CYP2C19 (CYP2C19*2) (OR(AA,AG) $=$ $=3,704 ; 95 \%$ CI 1,627-8,431)), GG гена CYP2D6 (CYP2D6*4) $(\mathrm{OR}(\mathrm{GG})=1,997 ; 95 \% \mathrm{CI} 1,050 \div 3,798))$, CT гена CYP3A4 (CYP3A4*1B), генотипа, гомозиготного по делеции гена GSTT1 (OR(DD) = 3,0; 95 \%CI 1,138-7,906)), и генотипа, гомозиготного по делециям в генах GSTT1 и GSTM1, генотипа AA гена NAT2 (c.803A>G) (OR(AA) = $=1,4 ; 95 \%$ CI 1,035-2,021)) и СС (c.282C>T) $(\mathrm{OR}(\mathrm{CC})=1,5 ; 95 \% \mathrm{CI} 1,092-2,095))$. Частых бронхолёгочных обострений и низкой эффективности антибактериальной терапии - с генотипами GG гена CYP2D6 (CYP2D6*4), CT гена CYP3A4 (CYP3A4*1B), CC гена GCLC (c.-129C>T). Неэффективности антисинегнойной терапии (в связи с низкими фармакокинетическими параметрами ципрофлоксацина) - с генотипами АА гена СҮР2С9 (c.1075A >C), генотип, гомозиготный по делеции гена GSTM1, генотип AA гена GSTP1 (c.313A>G) и генотипы, отличные от GCLC*7/7). НПР на антибактериальную терапию - с генотипами AA гена NAT2 (c.803A $>$ G), CC гена NAT2 (c.481C>T). Полипоза придаточных пазух носа (ПППН) - с генотипами CC гена NAT2 (c.282C $>$ T) $(\mathrm{OR}(\mathrm{CC})=2,566 ; 95 \% \mathrm{CI} 1,246-5,282))$, CС гена GCLC (c.-129C $>\mathrm{T})$, CT и TT гена GCLM (c.-588C $>\mathrm{T})(\mathrm{OR}(\mathrm{CT})=$ $=4,676 ; 95$ \% CI 1,639-13,349); цирроза печени с портальной гипертензией (ЦП) - генотип, гомозиготный по делеции гена GSTM1) (OR(DD) = 7,929; 95 \% CI 1,705-36,875) и комбинированных генотипов гена NAT2, соответствующих фенотипу медленного ацетилятора. Муковисцидоз-ассоциированного сахарного диабета (МЗСД) - с генотипами АС, СС по гену СYP2C9 (CYP2C9*3) (OR(AA) = 2,571; 95 \% CI 1,161-5,696)), СТ и TT варианта (CYP2C9*2), генотипом, гомозиготный по нефункциональному аллелю гена GSTT1 (OR(DD) $=6,413 ; 95 \%$ CI 1,335-30,805)).

\section{Заключение}

Выявлена ассоциация полиморфных вариантов генов семейства цитохрома Р-450 со снижением функции лёгких, предрасположенностью к патогенной флоре ДП, частым обострениям бронхолёгочного процесса с потребностью во внутривенной АБТ, МЗСД. Высокая активность фермента NAT2, по-видимому, снижает токсическую нагрузку на организм и эпителий дыхательного тракта, способствуя сохранению нормальных показателей функции лёгких. Медленное ацетилирование, следовательно, накопление токсичных метаболитов, ведёт к развитию НПР, те же процессы способствуют аггравации воспаления, что может создавать благоприятные условия для формирования ПППН. Различия в процессах биотрансформации определяют склонность К развитию осложнений МВ, связанных с хроническим воспалением, важную роль в котором играет глутатион, таких как ЦП, ПППН, МЗСД, и грамотрицательной инфекции у быстрых метаболизаторов, что влияет на функцию лёгких и частоту обострений, требующих проведения внутривенной АБТ и противовоспалительной терапии. Показано влияние изучаемых генов на фармакокинетику ципрофлоксацина. Полученные данные могут быть использованы для прогнозирования течения заболевания, определения подхода к АБТ.

\section{Список литературы / References}

1. Royal Brompton Hospital Clinical Guidelines: Care of Children with Cystic Fibrosis. 2020 (8th edition)

2. López-Causapé C Rojo-Molinero E, Macià MD, Oliver A. The problems of antibiotic resistance in cystic fibrosis and solutions. Expert Rev Respir Med. 2015;9(1):73-88. DOI: 10.1586/17476348.2015.995640.

3. Национальный консенсус «Муковисцидоз: определение, диагностические критерии, терапия» Под редакцией Е.И. Кондратьевой, Н.Ю. Каширской, Н.И. Капранова. Москва: ООО «Компания БОРГЕС»; 2016, 205 с. [Nacional'nyj konsensus «Mukoviscidoz: opredelenie, diagnosticheskie kriterii, terapiya» Pod redakciej EI Kondrat'evoj, NYu Kashirskoj, NI Kapranova. Moscow: OOO «Kompaniya BORGES»; 2016. (In Russ).].

4. Сычев Д.А. Сулейманов С.Ш., Кукес В.Г. Персонализированная медицина как путь к рациональному применению лекарственных средств: предпосылки, реалии, проблемы и перспективы для отечественной системы здравоохранения. Здравоохранение Дальнего Востока. 2010;43(1): 2-7. [Sychev DA, Suleymanov SSh, Kukes VG. Personalized medicine as a way to the rational use of medicines: background, realities, chal-lenges and prospects for national health care system. Zdravoohranenie Dal'nego Vostoka. 2010;43(1):2-7. (In Russ).].

5. Castellani C, Duff AJA, Bell SC, Heijerman HGM, Munck A, Ratjen F, Sermet-Gaudelus I, Southern KW, Barben J, Flume PA, 00000019.wmz P, Kashirskaya N, Kirszenbaum MN, Madge S, Oxley H, Plant B, Schwarzenberg SJ, Smyth AR, Taccetti G, Wagner TOF, Wolfe SP, Drevinek P. ECFS best practice guidelines: the 2018 revision. J Cyst Fibros. 2018 Mar; 17(2):153-178. DOI: 10.1016/j.jcf.2018.02.006. 